\title{
Evaluation of the Physicochemical, Structural, Thermal, and Behavioral Properties of the Energy of Consciousness Healing Treated Zinc Chloride
}

\author{
Mahendra Kumar Trivedi ${ }^{1}$, Alice Branton ${ }^{1}$, Dahryn Trivedi ${ }^{1}$, Gopal Nayak ${ }^{1}$, Michael Peter Ellis ${ }^{1}$, \\ James Jeffery Peoples ${ }^{1}$, James Joseph Meuer ${ }^{1}$, Johanne Dodon ${ }^{1}$, John Lawrence Griffin ${ }^{1}$, \\ John Suzuki ${ }^{1}$, Joseph Michael Foty ${ }^{1}$, Judy Weber ${ }^{1}$, Julia Grace McCammon ${ }^{1}$, Karen Brynes Allen ${ }^{1}$, \\ Kathryn Regina Sweas $^{1}$, Lezley Jo-Anne Wright ${ }^{1}$, Lisa A. Knoll ${ }^{1}$, Madeline E. Michaels ${ }^{1}$, \\ Margaret Kweya Wahl $^{1}$, Mark E. Stutheit ${ }^{1}$, Michelle Barnard ${ }^{1}$, Muriel Mae Ranger ${ }^{1}$, \\ Paromvong Sinbandhit ${ }^{1}$, V. J. Kris Elig ${ }^{1}$, Kalyan Kumar Sethi ${ }^{2}$, Parthasarathi Panda ${ }^{2}$, \\ Snehasis Jana, ${ }^{2, *}$ \\ ${ }^{1}$ Trivedi Global, Inc., Nevada, USA \\ ${ }^{2}$ Trivedi Science Research Laboratory Pvt. Ltd., Bhopal, India
}

Email address:

publication@trivedieffect.com (S. Jana)

${ }^{*}$ Corresponding author

To cite this article:

Mahendra Kumar Trivedi, Alice Branton, Dahryn Trivedi, Gopal Nayak, Michael Peter Ellis, James Jeffery Peoples, James Joseph Meuer, Johanne Dodon, John Lawrence Griffin, John Suzuki, Joseph Michael Foty, Judy Weber, Julia Grace McCammon, Karen Brynes Allen, Kathryn Regina Sweas, Lezley Jo-Anne Wright, Lisa A. Knoll, Madeline E. Michaels, Margaret Kweya Wahl, Mark E. Stutheit, Michelle Barnard, Muriel Mae Ranger, Paromvong Sinbandhit, V. J. Kris Elig, Kalyan Kumar Sethi, Parthasarathi Panda, Snehasis Jana. Evaluation of the Physicochemical, Structural, Thermal, and Behavioral Properties of the Energy of Consciousness Healing Treated Zinc Chloride. American Journal of Bioscience and Bioengineering. Vol. 5, No. 2, 2017, pp. 65-74. doi: 10.11648/j.bio.20170502.12

Received: February 27, 2017; Accepted: March 9, 2017; Published: April 1, 2017

\begin{abstract}
Zinc chloride is a source of zinc used in various pharmaceutical/nutraceutical formulations. The objective of the current study was to investigate the impact of The Trivedi Effect ${ }^{\mathbb{B}}$ - Energy of Consciousness Healing Treatment (Biofield Energy Treatment) on physical, structural, thermal, and behavioral properties of zinc chloride using PXRD, PSD, FT-IR, UVvis, and DSC analysis. Zinc chloride was divided into two parts - one part was control, while another part was treated with The Trivedi Effect ${ }^{\circledR}$ remotely by twenty renowned Biofield Energy Healers and defined as The Trivedi Effect ${ }^{\circledR}$ Treated sample. A significant alteration of the crystallite size and relative intensities of the PXRD peaks was observed in The Trivedi Effect ${ }^{\circledR}$ treated sample compared with the control sample. The average crystallite size of the treated sample was significantly increased by $23.18 \%$ compared with the control sample. The particle size values at $\mathrm{d}_{10}, \mathrm{~d}_{50}$, and $\mathrm{d}_{90}$ values were significantly decreased by $3.70 \%, 4.13 \%$, and $6.13 \%$, respectively in the treated sample compared with the control sample. Therefore, the surface area of the treated sample was increased by $4.21 \%$ compared with the control sample. The FT-IR spectroscopic analysis revealed that $\mathrm{Zn}-\mathrm{Cl}$ stretching in the control sample was found at $512 \mathrm{~cm}^{-1}$, whereas it was significantly shifted upward to $520 \mathrm{~cm}^{-1}$ in the treated sample. The UV-vis analysis exhibited that wavelength of the maximum absorbance $\left(\lambda_{\max }\right)$ of the control and treated samples were at $197.6 \mathrm{~nm}$ and $197.1 \mathrm{~nm}$, respectively. The DSC analysis exhibited that the melting temperature was decreased by $0.22 \%$, while decomposition temperature was increased by $2.56 \%$ in the treated sample compared to the control sample. The latent heat of fusion of the treated sample $(320.44 \mathrm{~J} / \mathrm{g})$ was significantly decreased by $16.70 \%$ compared with the control sample $(284.67 \mathrm{~J} / \mathrm{g})$. Similarly, the enthalpy of decomposition of the treated sample $(952.53 \mathrm{~J} / \mathrm{g})$ was significantly increased by $122.61 \%$ compared with the control sample $(427.90 \mathrm{~J} / \mathrm{g})$. Thus, the results indicated that the thermal stability of the treated zinc chloride was improved compared with the control sample. The current study anticipated that The Trivedi Effect ${ }^{\mathbb{R}}$ - Energy of Consciousness Healing Treatment might lead to produce a thermally stable new polymorphic form of zinc chloride, which would be more soluble and bioavailable compared with the untreated compound. Hence, the treated zinc chloride would be very useful to design better nutraceutical/pharmaceutical formulations that might offer better therapeutic response against
\end{abstract}


inflammatory diseases, immunological disorders, aging, stress, cancer, etc.

Keywords: Zinc Chloride, Consciousness Energy Healing Treatment, Biofield Energy Healers, The Trivedi Effect ${ }^{\circledR}$, PXRD, Particle Size, Surface Area, DSC

\section{Introduction}

Zinc is an essential element in human body due to its broad spectrum of physiological functions. It plays an important role in catalytic, structural or regulation in enzymes in the body, which involved in the nucleic acid and protein metabolism as well as for the production of energy. Zinc also maintains the structural integrity of the biological membranes resulting in their protection against oxidative injury [1-2]. As a metallotherapeutic agent, zinc possesses various pharmacological activities include fertility enhancing, retinoprotective, and putative antiviral activities [3]. Zinc is also used in the treatment of Wilson's disease [4]. It has also immunomodulatory and antioxidant activities [1]. Zinc is also used to prevent the development of several deficiency symptoms include parakeratosis, hypogeusia, anorexia, dysosmia, geophagia, hypogonadism, growth retardation, etc. [5-7]. Recently, it has been reported that zinc had increased the leukocyte count and phagocytic index, which potentiate the immunomodulatory effect along with Glycyrrhiza glabra [8]. Zinc chloride $\left(\mathrm{ZnCl}_{2}\right)$ is hygroscopic inorganic salt and highly soluble in water [9]. It is used in pharmaceutical industry as drug and diagnostic agent due to its powerful astringent and mild antiseptic properties [10]. It is also used in mouth-wash and deodorant preparations. Zinc chloride is used as dentin desensitizer i.e. reduces the sensitivity of the teeth to heat and cold. The other applications of zinc chloride include protein precipitation and insulin preparation $[10,11]$. Literature reported that zinc chloride has also been used in the treatment of cancer as a destructive agent [12] and in the pluripotency maintenance of mouse embryonic stem cell through the regulation of STAT3 signaling pathway [13]. It can be used for the palliative treatment of canine and malignant skin wounds [14]. It has the opposite effect on locomotor behavior of rats [15]. Therefore, zinc chloride was considered as one of the components in the novel proprietary herbomineral formulation for the source of zinc ion. This herbomineral formulation is designed as nutraceutical supplement and can be used for the prevention and treatment of various human disorders.

An élan vital or vital force which contributes the 'life' is preserved by every living organisms and known as prana by the Hindus, $q i$ or chi by the Chinese, and ki by the Japanese. This is believed to co-relate with the soul, spirit and mind. This hypothetical vital force is considered as the Biofield Energy. The Biofield Energy is infinite, paradimensional and dynamic electromagnetic field surrounding the human body. It can freely flow between the human and environment that leads to the continuous movement or matter of energy $[16,17]$. Thus, a human has the ability to harness energy from the earth, the "universal energy field" and transmit it to any living or nonliving object(s) around the globe. The objects always receive the energy and respond in a useful way. This process is known as Biofield Energy Healing Treatment [18, 19]. Biofield (Putative Energy Fields) based Energy Therapies are used worldwide to promote health and healing. The National Center of Complementary and Integrative Health (NCCIH) has been recognized and accepted Biofield Energy Healing as a Complementary and Alternative Medicine (CAM) health care approach in addition to other therapies, medicines and practices such as natural products, deep breathing, yoga, Tai Chi, Qi Gong, chiropractic/osteopathic manipulation, meditation, massage, special diets, homeopathy, progressive relaxation, guided imagery, acupressure, acupuncture, relaxation techniques, hypnotherapy, healing touch, movement therapy, pilates, rolfing structural integration, mindfulness, Ayurvedic medicine, traditional Chinese herbs and medicines, naturopathy, essential oils, aromatherapy, Reiki, cranial sacral therapy and applied prayer (as is common in all religions, like Christianity, Hinduism, Buddhism and Judaism) [20]. Biofield Energy Treatment (The Trivedi Effect ${ }^{\circledR}$ ) has been reported in numerous peer-reviewed science journals with significant outcomes in many scientific fields such as cancer research [21]; altered antimicrobial sensitivity of pathogenic microbes in microbiology [22-24], biotechnology [25, 26], genetics [27, 28]; changing the structure of the atom in relation to various metals, ceramics, polymers and chemicals [29, 30], altered physical and chemical properties of pharmaceuticals [31, 32], nutraceuticals [33, 34], organic compounds [35-37], and improved overall growth and yield of plants in agricultural science [38, 39]. The physicochemical properties such as particle size, crystalline structure, crystallite size, surface area, and thermal properties of a drug have a vital role in bioavailability as well as stability of the drug during processing, formulation, storage, and packaging [40, 41]. The particle size, specific surface area, crystalline nature, chemical and thermal behavior of an atom/ion might be altered by the Biofield Energy Healing Treatment (The Trivedi Effect ${ }^{\circledR}$ ) through possible mediation of neutrinos [42]. By considering all these aspects, powder X-ray diffraction (PXRD), particle size distribution analysis (PSD), Fourier transform infrared (FT-IR) spectrometry, ultraviolet-visible (UV-vis) spectroscopy, and differential scanning calorimetry (DSC) analytical techniques were conducted in this study for the characterization of physical, structural, and thermal properties of the Biofield Energy Treated and untreated zinc chloride.

\section{Materials and Methods}

\subsection{Chemicals and Reagents}

Zinc chloride was procured from Tokyo Chemical Industry Co., Ltd. (TCI), Japan. All other chemicals used in the experiment were of analytical grade available in India. 


\subsection{The Trivedi Effect ${ }^{\circledR}$ - Energy of Consciousness Healing Treatment Strategies}

Zinc chloride was one of the components of the new proprietary herbomineral formulation, developed by our research team and it was used per se as the test compound for the current study. The test compound was divided into two parts, one part of the test compound did not receive any sort of treatment and was defined as the untreated or control zinc chloride sample. The second part of the test compound was treated with The Trivedi Effect ${ }^{\mathbb{B}}$ - Energy of Consciousness Healing Treatment (Biofield Energy Treatment) by a group of twenty renowned Biofield Energy Healers remotely and was denoted as Biofield Energy Treated or The Trivedi Effect $^{\circledR}$ sample. Thirteen Biofield Energy Healers were remotely located in the U.S.A., five were located in Canada, and two were located in Australia, while the test compound was located in the research laboratory of GVK Biosciences Pvt. Ltd., Hyderabad, India. This Biofield Energy Treatment was provided for 5 minutes through Healer's Unique Energy Transmission process remotely to the test compound under the laboratory conditions. None of the Biofield Energy Healers in this study visited the laboratory in person, nor had any contact with the compounds. Similarly, the control compound was subjected to "sham" healers for 5 minutes, under the same laboratory conditions. The sham healer did not have any knowledge about the Biofield Energy Treatment. After that, the Biofield Energy Treated and untreated samples were kept in similar sealed conditions and characterized thoroughly by PXRD, PSD, FT-IR, UV-visible spectroscopy, and DSC analysis.

\subsection{Characterization}

\subsubsection{Powder X-Ray Diffraction (PXRD) Analysis}

The PXRD analysis was accomplished on PANalytical X'Pert Pro powder X-ray diffractometer system. The X-ray of wavelength $1.54056 \AA$ was used. The data was collected in

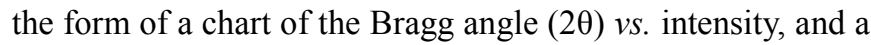
detailed table containing information on peak intensity counts, d value $(\AA)$, relative intensity (\%), full width half maximum (FWHM) $\left(\theta^{\circ}\right)$. From the PXRD results, the crystallite size $(G)$ was calculated using X'Pert data collector and X'Pert high score plus processing software. The crystallite size $(\mathrm{G})$ was calculated from the Scherrer equation $[43,44]$. The method was based on the width of the diffraction patterns obtained in the X-ray reflected the crystalline region. The crystallite size $(\mathrm{G})$ was calculated by using the following formula (1):

$$
\mathrm{G}=\mathrm{k} \lambda /(\mathrm{b} \operatorname{Cos} \theta)
$$

Where, $\mathrm{k}$ is the equipment constant $(0.5), \lambda$ is the $\mathrm{X}$-ray wavelength $(0.154 \mathrm{~nm})$; $\mathrm{b}$ in radians is the full-width at half of the peaks and $\theta$ the corresponding Bragg angle.

Percent change in crystallite size $(\mathrm{G})$ was calculated using following equation 2 :
$\%$ change in crystallite size $=\frac{\left[\mathrm{G}_{\text {Treated }}-\mathrm{G}_{\text {Control }}\right]}{\mathrm{G}_{\text {Control }}} \times 100$

Where, $G_{\text {Control }}$ and $G_{\text {Treated }}$ are the crystallite size of the control and Biofield Energy Treated samples, respectively.

A total of $\sim 500 \mathrm{mg}$ of the control and Biofield Energy Treated samples individually were used for the analysis and prepared by back loading technique using the sample preparation kit. The sample was spread on the holder ring in sufficient quantity to fill the ring cavity. It was then pressed down using powder press block and scrap the powder that was in surplus using a glass slide to get densely packed specimen. Consequently, the bottom plate was placed onto the holder ring and clamp in position. The sample holder was then removed from the sample preparation table by turning it upside down. A smooth surface of sample was obtained to ensure optimum results.

\subsubsection{Particle Size Distribution (PSD) Analysis}

The average particle size and particle size distribution were analyzed using Malvern Mastersizer 2000, UK with a detection range between $0.01 \mu \mathrm{m}$ to $3000 \mu \mathrm{m}$. The sample unit was filled with the dispersant medium and operated the stirrer at $2500 \mathrm{rpm}$. Alignment of the optics was done and the background measurement was taken. After the background measurement, the sample was added into the sample unit with constant monitoring the obscuration and stopped the addition of sample when the obscuration reached in between $15 \%$ to $20 \%$. When the obscuration was stable, the measurement was taken twice and the average of two measurements was taken. The average histogram of the two measurements was recorded. The data was presented in table format which include particle size $(\mu \mathrm{m})$. Also, the values at below $10 \%$ level $\left(\mathrm{d}_{10}\right), 50 \%$ level $\left(\mathrm{d}_{50}\right)$, and $90 \%$ level $\left(\mathrm{d}_{90}\right)$ were calculated from the histogram and the calculations such as surface area $\left(\mathrm{m}^{2} / \mathrm{g}\right)$ were done by using software Mastersizer 2000.

Percent change in particle size (d) for at below 10\% level $\left(\mathrm{d}_{10}\right), 50 \%$ level $\left(\mathrm{d}_{50}\right)$, and $90 \%$ level $\left(\mathrm{d}_{90}\right)$ was calculated using following equation 3 :

$$
\% \text { change in particle size }=\frac{\left[\mathrm{d}_{\text {Treated }}-\mathrm{d}_{\text {Control }}\right]}{\mathrm{d}_{\text {Control }}} \times 100
$$

Where, $d_{\text {Control }}$ and $d_{\text {Treated }}$ are the particle size $(\mu \mathrm{m})$ for at below $10 \%$ level $\left(\mathrm{d}_{10}\right), 50 \%$ level $\left(\mathrm{d}_{50}\right)$, and $90 \%$ level $\left(\mathrm{d}_{90}\right)$ of the control and Biofield Energy Treated samples, respectively.

Percent change in surface area (S) was calculated using following equation 4 :

$$
\% \text { change in surface area }=\frac{\left[\mathrm{S}_{\text {Treated }}-\mathrm{S}_{\text {Control }}\right]}{\mathrm{S}_{\text {Control }}} \times 100
$$

Where, $\mathrm{S}_{\text {Control }}$ and $\mathrm{S}_{\text {Treated }}$ are the surface area of the control and Biofield Energy Treated samples, respectively.

\subsubsection{Fourier Transform Infrared (FT-IR) Spectroscopy}

FT-IR spectroscopy of zinc chloride was performed on Spectrum two (Perkin Elmer, USA) Fourier transform infrared spectrometer with the frequency array of 400-4000 $\mathrm{cm}^{-1}$ by using pressed $\mathrm{KBr}$ disk technique. 


\subsubsection{Ultraviolet-Visible Spectroscopy (UV-Vis) Analysis}

The UV-Vis spectral analysis was carried out using Shimadzu UV-2450 with UV Probe, Japan. The spectrum was recorded using $1 \mathrm{~cm}$ quartz cell that has a slit width of $1.0 \mathrm{~nm}$. The wavelength range chosen for recording the spectra was $190-800 \mathrm{~nm}$. The absorbance spectra (in the range of 0.2 to 0.9 ) and wavelength of maximum absorbance $\left(\lambda_{\max }\right)$ were recorded.

\subsubsection{Differential Scanning Calorimetry (DSC)}

Analysis was performed using the DSC Q20 (TA
Instruments, USA) differential scanning calorimeter. A total of $\sim 5 \mathrm{mg}$ sample was weighed and sealed in aluminum pans and equilibrated at $25^{\circ} \mathrm{C}$ and heated up to $450^{\circ} \mathrm{C}$ at the heating rate of $10^{\circ} \mathrm{C} / \mathrm{min}$ under nitrogen gas as purge atmosphere with flow rate of $50 \mathrm{~mL} / \mathrm{min}$. The value for onset, endset, peak temperature, peak height ( $\mathrm{mJ}$ or $\mathrm{mW}$ ), peak area, and change in heat $(\mathrm{J} / \mathrm{g})$ for each peak were recorded.

Percent change in the melting/decomposition temperature (T) was calculated using following equation 5 :

$$
\% \text { change in melting/decomposition temperature }=\frac{\left[\mathrm{T}_{\text {Treated }}-\mathrm{T}_{\text {Control }}\right]}{\mathrm{T}_{\text {Control }}} \times 100
$$

Where, $\mathrm{T}_{\text {Control }}$ and $\mathrm{T}_{\text {Treated }}$ are the decomposition temperature of the control and Biofield Energy Treated samples, respectively.

Percent change in the enthalpy of melting/decomposition $(\Delta \mathrm{H})$ was calculated using following equation 6 :

$$
\% \text { change in latent heat of } \frac{\text { melting }}{\text { decomposition }}=\frac{\left[\Delta \mathrm{H}_{\text {Treated }}-\Delta \mathrm{H}_{\text {Control }}\right]}{\Delta \mathrm{H}_{\text {Control }}} \times 100
$$

Where, $\Delta \mathrm{H}_{\text {Control }}$ and $\Delta \mathrm{H}_{\text {Treated }}$ are the enthalpy of decomposition of the control and Biofield Energy Treated samples, respectively.

\section{Results and Discussion}

\subsection{Powder X-ray Diffraction (PXRD) Analysis}

The PXRD diffractograms of both the control and Biofield Energy Treated zinc chloride are presented in Figure 1. Both the samples displayed very sharp and intense peaks in their respective diffractogram indicating the crystalline nature of zinc chloride. PXRD data such as Bragg angle (20), relative intensity $(\%)$, full width half maximum (FWHM) $\left(\theta^{\circ}\right)$, and crystallite size (G) for the control and Biofield Energy Treated zinc chloride are presented in the Table 1 . The crystallite size was calculated with the help of Scherrer equation $[43,44]$. The crystallite size of the control and Biofield Energy Treated samples were found to be similar at $2 \theta$ equal to nearly $48.6^{\circ}, 56.2^{\circ}$, and $70.5^{\circ}$ (Table 1 , entry 6,9 , and 13). The crystallite size of the Biofield Energy Treated zinc chloride at $2 \theta$ equal to nearly $15.6^{\circ}, 25.4^{\circ}, 29.3^{\circ}$, $34.8^{\circ}, 38.2^{\circ}, 52.3^{\circ}, 57.4^{\circ}$, and $72.1^{\circ}$ (Table 1 , entry $1-5,8,10$, and 14 ) was significantly increased in the range of $14.28 \%$ to $200.15 \%$ compared with the control sample. Consequently, at $2 \theta$ equal to $49.2^{\circ}, 58.3^{\circ}$, and $61.8^{\circ}$ (Table 1 , entry 7,11 , and 12 ), the crystallite size of the Biofield Energy Treated zinc chloride was significantly decreased from $24.93 \%$ to $49.95 \%$ with respect to the control sample. However, the average crystallite size of the Biofield Energy Treated sample was significantly increased by $23.18 \%$ (Table 1 , entry 15 ) with respect to the control sample. The PXRD diffractogram of the Biofield Energy Treated zinc chloride displayed greater intensity at Bragg's angle (20) equal to $49.2^{\circ}$ (Table 1 , entry 7 ), whereas it was found at $48.6^{\circ}$ (Table 1 , entry 6 ) in the control sample. Beside this, the relative intensities of the PXRD peaks (Table 1) in the Biofield Energy Treated sample were significantly altered compared with the control sample.

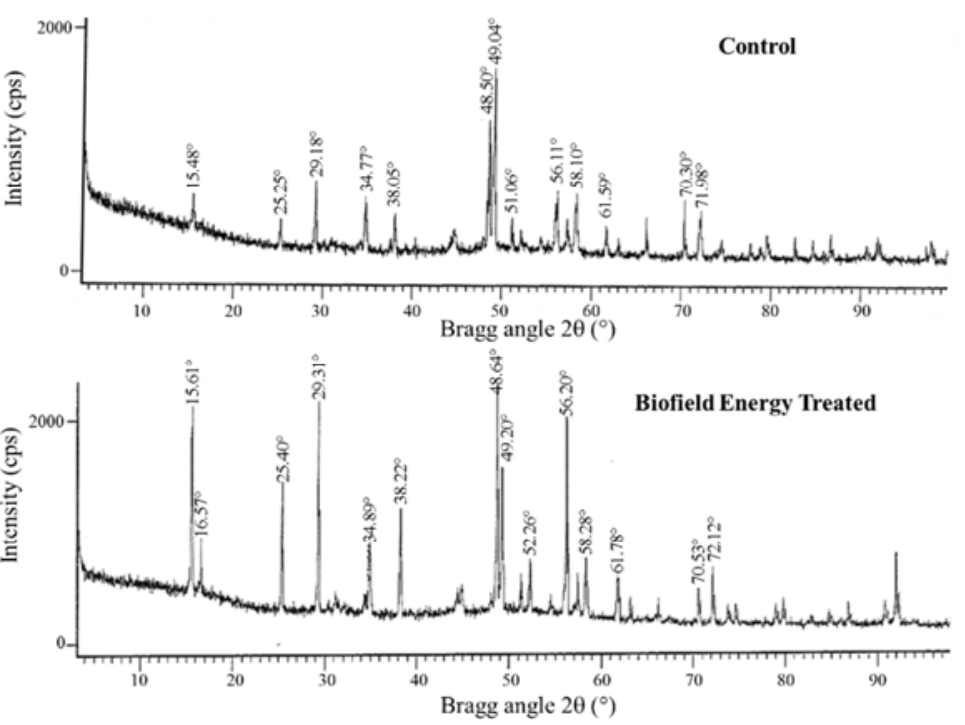

Figure 1. PXRD diffractograms of the control and Biofield Energy Treated zinc chloride. 
Table 1. PXRD data of the control and Biofield Energy Treated zinc chloride.

\begin{tabular}{|c|c|c|c|c|c|c|c|c|c|}
\hline \multirow{2}{*}{$\begin{array}{l}\text { Entry } \\
\text { No. }\end{array}$} & \multicolumn{2}{|c|}{ Bragg angle $\left({ }^{\circ} 2 \theta\right)$} & \multicolumn{2}{|c|}{ Relative Intensity (\%) } & \multicolumn{2}{|c|}{ FWHM $\left({ }^{\circ} 2 \theta\right)$} & \multicolumn{3}{|c|}{ Crystallite size $(\mathbf{G}, \mathbf{n m})$} \\
\hline & Control & Treated & Control & Treated & Control & Treated & Control & Treated & $\%$ change \\
\hline 1 & 15.48 & 15.61 & 18.51 & 85.15 & 0.1338 & 0.1171 & 33.20 & 37.94 & 14.28 \\
\hline 2 & 25.25 & 25.40 & 14.52 & 58.89 & 0.1673 & 0.0669 & 26.97 & 67.45 & 150.15 \\
\hline 3 & 29.18 & 29.31 & 35.38 & 93.23 & 0.0669 & 0.0502 & 68.00 & 90.65 & 33.31 \\
\hline 4 & 34.77 & 34.80 & 22.85 & 28.54 & 0.1673 & 0.0816 & 27.58 & 56.54 & 105.04 \\
\hline 5 & 38.05 & 38.22 & 18.11 & 48.01 & 0.2007 & 0.0669 & 23.21 & 69.65 & 200.15 \\
\hline 6 & 48.50 & 48.64 & 68.70 & 100.00 & 0.0816 & 0.0816 & 59.19 & 59.22 & 0.06 \\
\hline 7 & 49.04 & 49.20 & 100.00 & 64.20 & 0.0612 & 0.0816 & 79.09 & 59.36 & -24.95 \\
\hline 8 & 51.06 & 52.26 & 17.73 & 24.00 & 0.0816 & 0.0612 & 59.81 & 80.16 & 34.01 \\
\hline 9 & 56.11 & 56.20 & 30.24 & 87.20 & 0.0816 & 0.0816 & 61.17 & 61.19 & 0.04 \\
\hline 10 & 57.18 & 57.41 & 15.76 & 19.63 & 0.1224 & 0.0616 & 40.98 & 81.53 & 98.92 \\
\hline 11 & 58.10 & 58.28 & 24.94 & 25.53 & 0.1224 & 0.1632 & 41.17 & 30.90 & -24.93 \\
\hline 12 & 61.59 & 61.78 & 15.05 & 18.74 & 0.102 & 0.204 & 50.28 & 25.16 & -49.95 \\
\hline 13 & 70.30 & 70.53 & 30.97 & 19.55 & 0.0612 & 0.0612 & 88.06 & 88.19 & 0.14 \\
\hline 14 & 71.98 & 72.12 & 19.20 & 25.30 & 0.1632 & 0.1224 & 33.37 & 44.54 & 33.45 \\
\hline 15 & \multicolumn{2}{|c|}{ Average crystallite size } & & & & & 49.43 & 60.89 & 23.18 \\
\hline
\end{tabular}

FWHM: Full width half maximum, "denotes the percentage change in the crystallite size of the Biofield Energy Treated sample with respect to the control sample.

Scientific literature reported that the changes in the XRD patterns, such as crystallite size and relative intensities, indicated the modification of the morphology of the crystal as well as the proof of polymorphic transition [45-47]. As the crystal morphology of the Biofield Energy Treated sample was altered compared with the control sample, the Biofield Energy Treated sample might be a new polymorphic form of zinc chloride. The crystal pattern, size and even polymorphic form of a pharmaceutical play important roles in drug solubility, dissolution and bioavailability. It has been reported in the literature that the alteration in crystal morphology has significant impact on the in vitro dissolution rate, which is related with the bioavailability of orally administered pharmaceutical/nutraceutical [41]. So, it can be concluded that the Biofield Energy Healing Treatment might be a very useful method for enhancing the bioavailability of zinc chloride.

\subsection{Particle Size Distribution (PSD) Analysis}

The particle size values $\left(d_{10}, d_{50}\right.$, and $\left.d_{90}\right)$ and the average surface area of the control and Biofield Energy Treated zinc chloride were investigated and the results are presented in the Table 2. It was evident that the Biofield Energy Treatment has the ability to reduce the particle size $\left(\mathrm{d}_{10}, \mathrm{~d}_{50}\right.$, and $\left.\mathrm{d}_{90}\right)$ of zinc chloride with respect to the control sample. The size of the particles at below $10 \%$ level $\left(\mathrm{d}_{10}\right), 50 \%$ level $\left(\mathrm{d}_{50}\right)$, and $90 \%$ level $\left(\mathrm{d}_{90}\right)$ were decreased by $3.70 \%, 4.13 \%$, and $6.13 \%$, respectively in the Biofield Energy Treated sample compared to the control sample.

Table 2. Particle size data $\left(d_{10}, d_{50}\right.$, and $\left.d_{90}\right)$ and surface area of the control and Biofield Energy Treated zinc chloride.

\begin{tabular}{lllll}
\hline Parameter & $\mathbf{d}_{\mathbf{1 0}}(\boldsymbol{\mu m})$ & $\mathbf{d}_{\mathbf{5 0}}(\boldsymbol{\mu m})$ & $\mathbf{d}_{\mathbf{9 0}}(\boldsymbol{\mu m})$ & Surface $\operatorname{area}\left(\mathbf{m}^{2} / \mathbf{g}\right)$ \\
\hline Control & 0.973 & 2.591 & 6.023 & 3.09 \\
Biofield Energy Treated & 0.937 & 2.484 & 5.654 & 3.22 \\
Percent change (\%)* & -3.70 & -4.13 & -6.13 & 4.21 \\
\hline
\end{tabular}

*denotes the percentage change in the particle size data $\left(d_{10}, d_{50}\right.$, and $\left.d_{90}\right)$ and surface area of the Biofield Energy Treated sample with respect to the control sample.

The particle size and surface area have a major effect on dissolution of a compound in a solvent, because the surface energy influenced by the surface area and chemical affinity is the driving factor for dissolution efficiency [48, 49]. The surface area for both the control and Biofield Energy Treated zinc chloride samples were analyzed and the results are presented in Table 2. The control sample showed surface area of $3.09 \mathrm{~m}^{2} / \mathrm{g}$ and it was increased to $3.22 \mathrm{~m}^{2} / \mathrm{g}$ in the Biofield Energy Treated zinc chloride. The surface area of the Biofield Energy Treated sample increased by $4.21 \%$ compared with the control sample.

Poorly crystallized compounds possess more surface area and higher exchange capacities than well-crystallized compounds [50]. In addition, the variation of the crystal morphology in the Biofield Energy Treated sample, which was well-supported from PXRD data, may cause to alter the surface area of the Biofield Energy Treated zinc chloride compared with the control sample. It has been well established that the particle size, shape and surface area of pharmaceutical compounds have an important impact on solubility, dissolution and in vivo bioavailability, as well as supports the designing of new drug delivery systems [51, 52]. Reducing the particle size and higher surface area would enhance the solubility of the solid particles, and consequently would increase the dissolution rate and bioavailability [53]. Thus, it is assumed that the Biofield Energy Treated zinc chloride might be dissolved and absorbed at a faster rate and may possibly have more bioavailability than untreated zinc chloride. 


\subsection{Fourier Transform Infrared (FT-IR) Spectroscopy}

The FT-IR spectra of the control and Biofield Energy Treated samples of zinc chloride are presented in the Figure 2. The characteristic peaks were observed at 3904, 3583, 3518, 1931, 1609, 986, and $512 \mathrm{~cm}^{-1}$ in the control FT-IR spectrum (Figure 2). On the other hand, the FT-IR spectrum of the Biofield Energy Treated zinc chloride showed the notable absorption bands at 3905, 3583, 3519, 1931, 1608, 985, and $520 \mathrm{~cm}^{-1}$ (Figure 2). The strong and broad absorption band centered near $3583 \mathrm{~cm}^{-1}$ and the H-O-H bending motion at $1608 \mathrm{~cm}^{-1}$ that were due to the presence of the lattice water were found in the FT-IR spectrum of both the control and Biofield Energy Treated samples (Figure 2). Literature suggested that the metal-halide stretching absorption band for inorganic materials generally found in the $750-100 \mathrm{~cm}^{-1}$ region [54]. In control spectrum, metal-halogen $(\mathrm{Zn}-\mathrm{Cl})$ stretching was found at $512 \mathrm{~cm}^{-1}$, whereas it was shifted upward in the Biofield Energy Treated sample at $520 \mathrm{~cm}^{-1}$. Overall, FT-IR results suggest that there may be a significant impact of Biofield Energy Treatment on zinc chloride at the atomic level to increase the force constant of $\mathrm{Zn}-\mathrm{Cl}$ bonds. This result also supported with the PXRD data that Biofield Energy Treated sample might be new polymorphic form of zinc chloride.
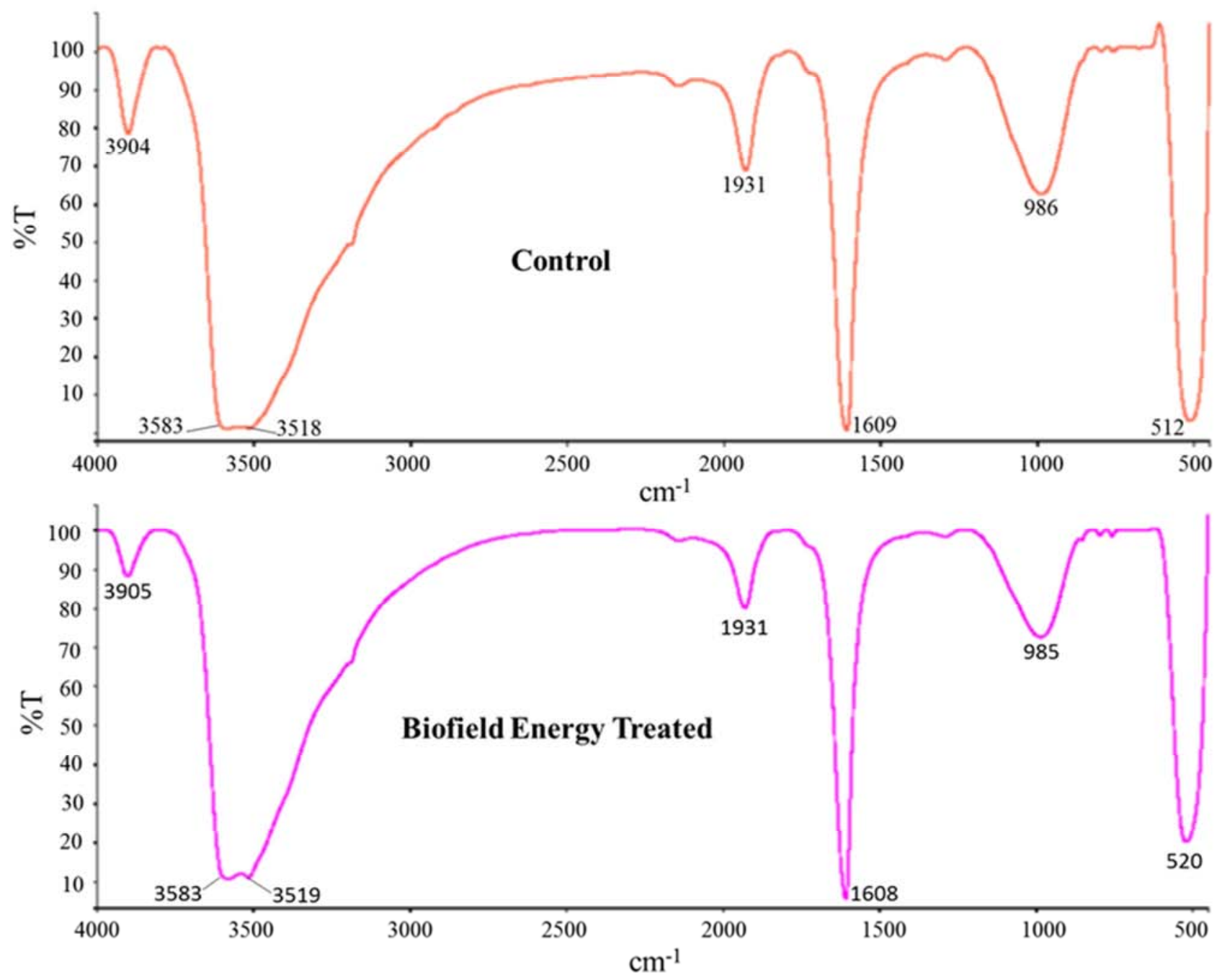

Figure 2. FT-IR spectra of the control and Biofield Energy Treated zinc chloride.

\subsection{Ultraviolet-Visible Spectroscopy (UV-Vis) Analysis}

The UV-visible spectra of both the control and Biofield Energy Treated zinc chloride are presented in the Figure 3. The spectra of control and Biofield Energy Treated sample showed the maximum absorbance $\left(\lambda_{\max }\right)$ at $197.6 \mathrm{~nm}$ and $197.1 \mathrm{~nm}$, respectively, along with similar shift of absorbance maxima from 1.4723 in control and 1.4727 in Biofield Energy Treated sample. The UV absorbance occurs due to the diverse type of energy transitions from the singlet to the singlet excited state such as $\sigma \rightarrow \sigma^{*}, \mathrm{n} \rightarrow \pi^{*}$, and $\pi \rightarrow \pi^{*}$. These type of electronic transitions are occurred when the difference in energy between the lowest unoccupied molecular orbital (LUMO) and the highest occupied molecular orbital (HOMO) is significantly higher than the activation energy of the compound [55]. The UV-vis spectroscopic analysis of zinc chloride displayed no change in the $\lambda_{\max }$ of the Biofield Energy Treated sample compared to the control sample. Thus, the structural configuration or activation energy of the Biofield Energy Treated sample was not changed compared with the control sample. 


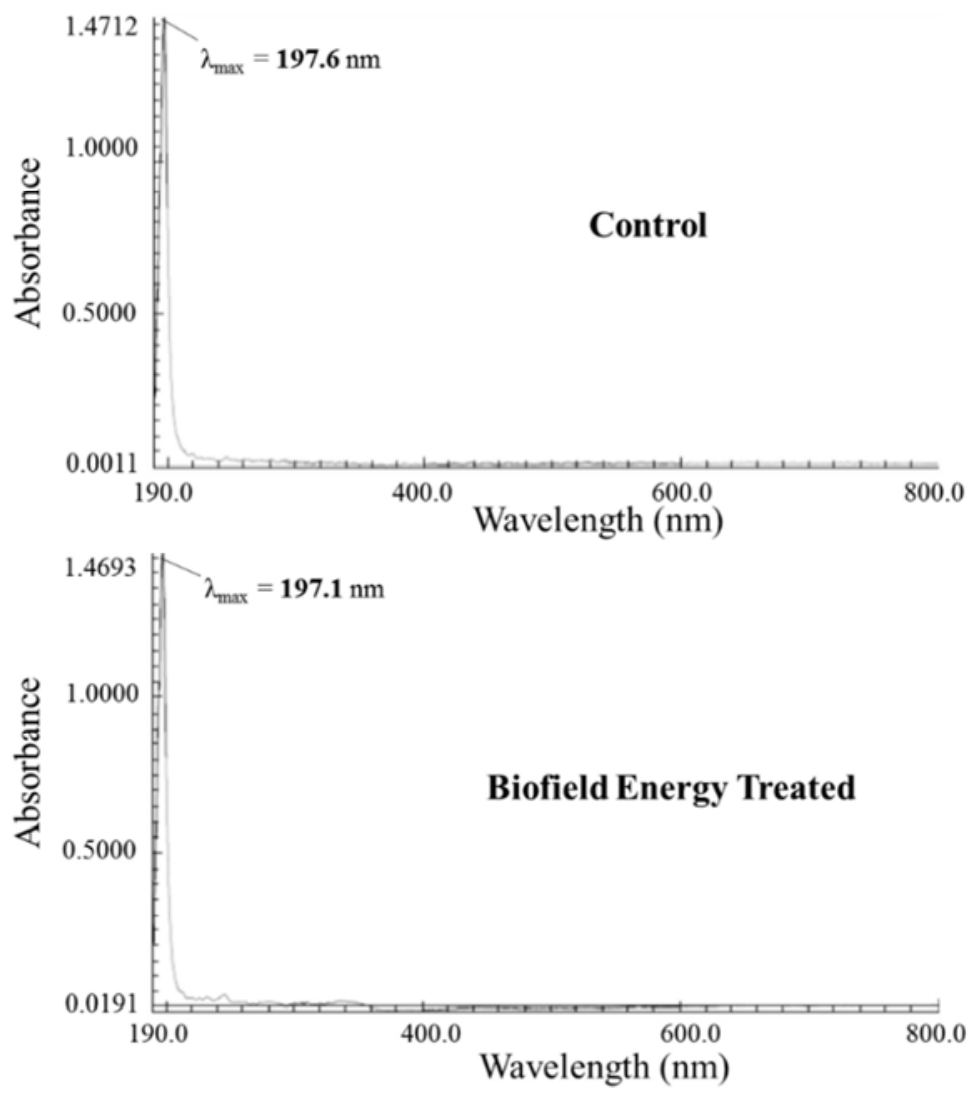

Figure 3. UV-Vis spectra of the control and Biofield Energy Treated zinc chloride.

\subsection{Differential Scanning Calorimetry (DSC) Analysis}

The DSC thermograms of the control and Biofield Energy Treated zinc chloride are presented in the Figure 4. The melting/decomposition temperature and enthalpy of fusion/decomposition of the control and Biofield Energy Treated zinc chloride are presented in the Table 3. The melting/fusion temperature was slightly decreased by $0.22 \%$ in the Biofield Energy Treated zinc chloride $\left(311.01^{\circ} \mathrm{C}\right)$ compared with the control sample $\left(311.71^{\circ} \mathrm{C}\right)$. The onset melting temperature was increased by $1.47 \%$ and the endset temperature was decreased slightly by $0.26 \%$ in the Biofield Energy Treated sample compared with the control sample. The latent heat of fusion or enthalpy of fusion $\left(\Delta \mathrm{H}_{\text {fusion }}\right)$ of the control and Biofield Energy Treated zinc chloride was $384.67 \mathrm{~J} / \mathrm{g}$ and $320.44 \mathrm{~J} / \mathrm{g}$, respectively. The $\Delta \mathrm{H}_{\text {fusion }}$ of the Biofield Energy Treated sample was significantly decreased by $16.70 \%$ compared with the control sample. Similarly, the decomposition temperature of the Biofield Energy Treated zinc chloride $\left(384.29^{\circ} \mathrm{C}\right)$ was increased by $2.56 \%$ compared to the control sample (392.59C). The onset and endset decomposition temperature was increased by $1.95 \%$ and $2.83 \%$ in the Biofield Energy Treated sample compared with the control sample. The enthalpy of decomposition $\left(\Delta \mathrm{H}_{\text {decomposition }}\right)$ of the control and Biofield Energy Treated zinc chloride were $427.90 \mathrm{~J} / \mathrm{g}$ and $952.53 \mathrm{~J} / \mathrm{g}$, respectively. The $\Delta \mathrm{H}_{\text {decomposition }}$ of the Biofield Energy Treated sample was significantly increased by $122.61 \%$ compared with the control sample. Overall, results indicated that the zinc chloride need more energy in the form of latent heat to undergo the process of decomposition after Biofield Energy Treatment. It is anticipated that Biofield Energy Treatment might enhance the internal energy in zinc chloride that leads to increase of the decomposition temperature and the enthalpy of decomposition and ultimately to enhance the overall thermal stability of the Biofield Energy Treated sample significantly compared with the untreated sample. The enhanced thermal stability of a drug is an advantage in the maintenance of the product in long term storage condition throughout the shelf-life for any pharmaceutical formulations [56].

Table 3. The latent heat of fusion $(\mathrm{J} / \mathrm{g})$, enthalpy of decomposition $(\mathrm{J} / \mathrm{g})$ and melting/decomposition temperature $\left({ }^{\circ} \mathrm{C}\right)$ values of the control and Biofield Energy Treated zinc chloride.

\begin{tabular}{|c|c|c|c|c|c|}
\hline $\begin{array}{l}\text { Endothermic } \\
\text { peak }\end{array}$ & Description & $\begin{array}{l}\mathbf{T}_{\text {onset }} \\
\left({ }^{\circ} \mathrm{C}\right) \\
\end{array}$ & $\begin{array}{l}\mathbf{T}_{\text {peak }} \\
\left({ }^{\circ} \mathrm{C}\right)\end{array}$ & $\begin{array}{l}\mathbf{T}_{\text {endset }} \\
\left({ }^{\circ} \mathbf{C}\right)\end{array}$ & $\begin{array}{l}\Delta \mathbf{H} \\
(\mathbf{J} / \mathbf{g})\end{array}$ \\
\hline \multirow{2}{*}{$\begin{array}{l}\text { Endothermic } \\
\text { peak }\end{array}$} & \multirow{2}{*}{$\begin{array}{l}\text { Control sample } \\
\text { Biofield Energy } \\
\text { Treated sample }\end{array}$} & 298.96 & 311.71 & 316.68 & 384.67 \\
\hline & & 303.34 & 311.01 & 315.87 & 320.44 \\
\hline \multicolumn{2}{|l|}{$\%$ Change* } & 1.47 & -0.22 & -0.26 & -16.70 \\
\hline \multirow{2}{*}{$\begin{array}{l}\text { Exothermic } \\
\text { peak }\end{array}$} & \multirow{3}{*}{$\begin{array}{l}\text { Control sample } \\
\text { Biofield Energy } \\
\text { Treated sample }\end{array}$} & 381.03 & 384.29 & 385.16 & 427.90 \\
\hline & & 388.47 & 392.59 & 396.05 & 952.53 \\
\hline$\%$ Change* & & 1.95 & 2.56 & 2.83 & 122.61 \\
\hline $\begin{array}{l}T_{\text {onset }} \text { Onset } \\
\text { melting/decomp } \\
\text { temperature, } \Delta H \\
\text { change of the } E\end{array}$ & \multicolumn{2}{|c|}{$\begin{array}{l}\text { melting/decomposition } \\
\text { ition temperature, } T_{\text {endset }} \text { : } \\
\text { Enthalpy of fusion/decomp } \\
\text { ofield Enerov Treated sam }\end{array}$} & $\begin{array}{l}\text { mpera } \\
\text { indset }\end{array}$ & $T_{p}$ & $\begin{array}{r}\text { Peak } \\
\text { position } \\
\text { ccentage }\end{array}$ \\
\hline
\end{tabular}



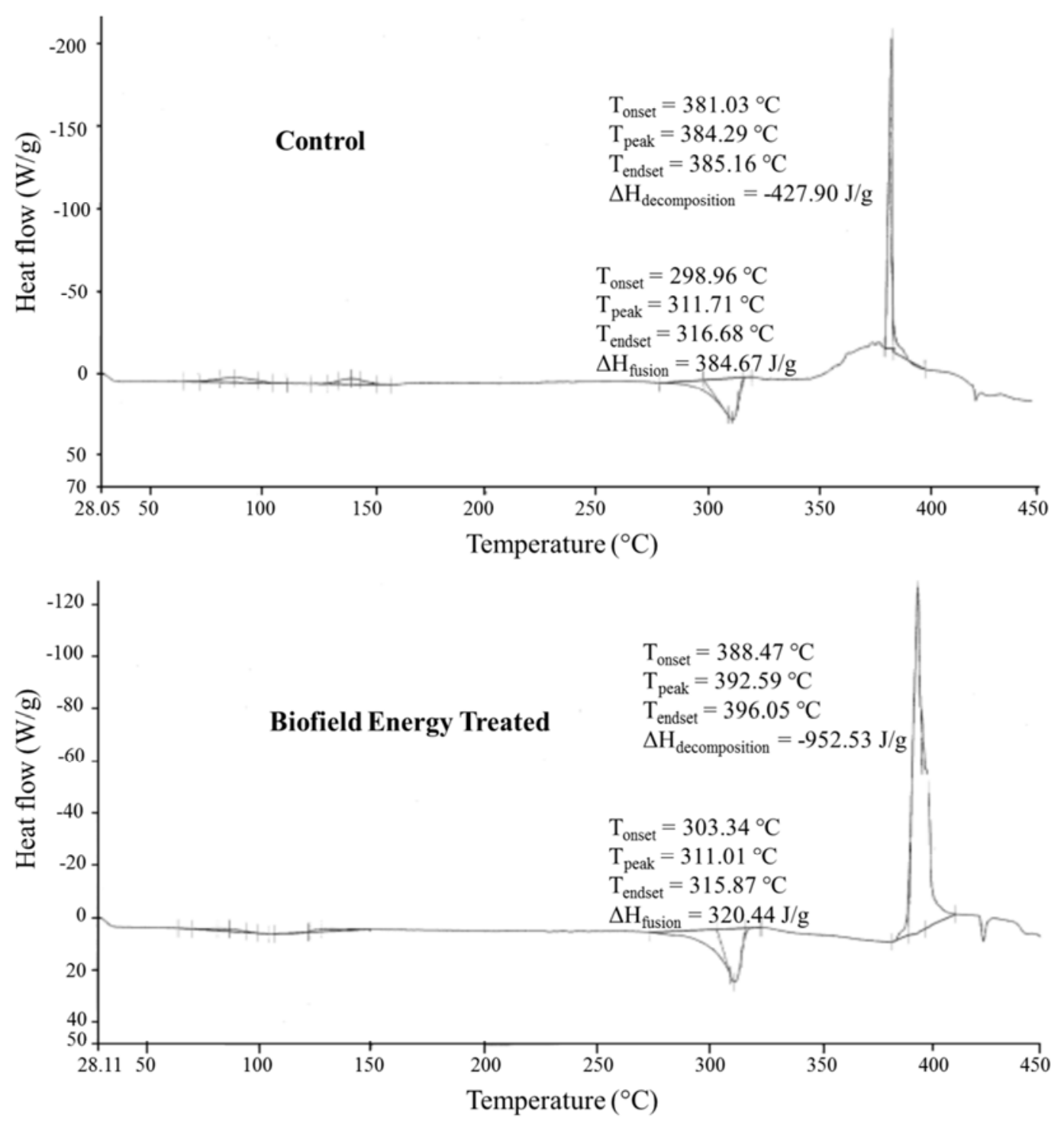

Figure 4. DSC thermograms of the control and Biofield Energy Treated zinc chloride.

\section{Conclusions}

The current study revealed that The Trivedi Effect ${ }^{\circledR}$ Energy of Consciousness Healing Treatment had the significant effects on the physical, structural, thermal, and behavioral properties of zinc chloride. The PXRD data displayed the significant alteration of the crystallite size and relative intensities of the PXRD peaks in The Trivedi Effect ${ }^{\circledR}$ treated sample compared with the control sample. The average crystallite size of the treated sample was significantly increased by $23.18 \%$ compared with the control sample. The particle size values at $\mathrm{d}_{10}, \mathrm{~d}_{50}$, and $\mathrm{d}_{90}$ were significantly decreased by $3.70 \%, 4.13 \%$, and $6.13 \%$, respectively in the treated sample compared with the control sample. Therefore, the surface area of the treated sample was increased by $4.21 \%$ compared with the control sample. The FT-IR spectroscopic analysis revealed that $\mathrm{Zn}-\mathrm{Cl}$ stretching in the control sample was $512 \mathrm{~cm}^{-1}$, whereas it was significantly shifted upward to $520 \mathrm{~cm}^{-1}$ in the treated sample. The DSC analysis exhibited that the melting temperature was decreased by $0.22 \%$, while decomposition temperature was increased by $2.56 \%$ in the treated sample compared to the control sample. The latent heat of fusion of the treated sample was significantly decreased by $16.70 \%$ compared with the control sample. Similarly, the enthalpy of decomposition of the treated sample was significantly increased by $122.61 \%$ compared with the control sample. The results indicated that the thermal stability of the treated zinc chloride was improved compared with the control sample. Thus, the treated sample could be more stable during manufacturing, delivery or storage conditions than the untreated sample. Briefly, The Trivedi Effect $\left.{ }^{(}\right)$Energy of Consciousness Healing Treatment might introduce a new thermally stable polymorphic form of zinc chloride that could be more soluble and bioavailable compared with the untreated compound. Hence, Biofield Energy Treated zinc chloride would be very useful to design better nutraceutical and/or pharmaceutical formulations that might offer better therapeutic response against inflammatory diseases, 
immunological disorders, aging, stress, cancer, Wilson's disease, viral diseases, parakeratosis, hypogeusia, anorexia, dysosmia, geophagia, hypogonadism, growth retardation, etc.

\section{Abbreviations}

DSC: Differential scanning calorimetry, FT-IR: Fourier transform infrared spectroscopy, FWHM: Full width half maximum, G: Crystallite size, HOMO: Highest energy occupied molecular orbital, LUMO: Lowest energy unoccupied molecular orbital, $\mathrm{T}_{\text {onset }}$ : Onset melting/decomposition temperature, $\mathrm{T}_{\text {peak }}$ : Peak melting/decomposition temperature, $\mathrm{T}_{\text {endset }}$ Endset melting/decomposition temperature, $\Delta \mathrm{H}$ : Enthalpy of fusion/decomposition, UV-vis: Ultraviolet-visible spectroscopy, PSD: Particle size distribution, PXRD: Powder $\mathrm{X}$-ray diffraction.

\section{Acknowledgements}

The authors are grateful to GVK Biosciences Pvt. Ltd., Trivedi Science, Trivedi Global, Inc. and Trivedi Master Wellness for their assistance and support during this work.

\section{References}

[1] Ronconi L, Sadler PJ. (2008) Applications of heteronuclear NMR spectroscopy in biological and medicinal inorganic chemistry. Coordn Chem Rev 252: 2239-2277.

[2] Berg JM, Shi Y. (1996) The galvanization of biology: A. growing appreciation for the roles of zinc. Science 271: 10811085.

[3] Higdon JV, Ho E. (2005) In: M. Gielen, E. R. T. Tiekink (Eds.), Metallotherapeutic drugs and metal-based diagnostic agents: The use of metals in medicine, Wiley-VCH, Weinheim, p. 237.

[4] Brewer GJ. (2001) Zinc acetate for the treatment of Wilson's disease. Expert Opin Pharmacother 2: 1473-1477.

[5] Prasad AS. (1979) Clinical, biochemical, and pharmacological role of zinc. Ann Rev Pharmacol Toxicol 19: 393-426.

[6] Supuran CT. (2008) Carbonic anhydrases: Novel therapeutic applications for inhibitors and activators. Nat Rev Drug Dis 7: 168-181.

[7] Elmes ME. (1975) Letter: Zinc in human medicine. Lancet 2: 549 .

[8] Mazumder PM, Pattnayak S, Parvani H, Sasmal D, Rathinavelusamy P. (2012) Evaluation of immunomodulatory activity of Glycyrhiza glabra L. roots in combination with zing. Asian Pac J Trop Biomed 2: S15-S20.

[9] Brynestad J, Yakel HL. (1978) Preparation and structure of anhydrous zinc chloride. Inorg Chem 17: 1376-1377.

[10] Kasture AV, Wadodkar SG. (2008) A. text book of pharmaceutical chemistry-1, Nirali Prakashan, $25^{\text {th }}$ Ed., Pune, India.

[11] Mahadik KR, Kuchekar BS. (2008) Concise inorganic pharmaceutical chemistry, Nirali Prakashan, 25 $5^{\text {th }}$ Ed., Pune, India.

[12] McDaniel S, Goldman GD. (2002) Consequences of using escharotic agents as primary treatment for nonmelanoma skin cancer. Arch Dermatol 138: 1593-1596.

[13] Hu J, Yang Z, Wang J, Yu J, Guo J, Liu S, Qian C, Song L, Wu Y, Cheng J. (2016) Zinc chloride transiently maintains mouse embryonic stem cell pluripotency by activating Stat3 signaling. PLoS One 11: e0148994.

[14] Fukuyama Y, Kawarai S, Tezuka T, Kawabata A, Maruo T. (2016) The palliative efficacy of modified Mohs paste for controlling canine and feline malignant skin wounds. Vet Q. 1: $1-7$.

[15] Yakimovskii AF, Kryzhanovskaya SY. (2015) Zinc chloride and zinc acetate injected into the neostriatum produce opposite effect on locomotor behavior of rats. Bull Exp Biol Med 160: 281-282.

[16] Stenger VJ. (1999) Bioenergetic fields. Sci Rev Alternative Med 3: 16-21.

[17] Rogers, M. (1989) "Nursing: A. Science of Unitary Human Beings." In J. P. Riehl-Sisca (ed.) Conceptual Models for Nursing Practice. $3^{\text {rd }}$ Edn. Norwark: Appleton \& Lange.

[18] Rosa L, Rosa E, Sarner L, Barrett S. (1998) A. close look at therapeutic touch. Journal of the American Medical Association 279: 1005-1010.

[19] Warber SL, Cornelio D, Straughn, J, Kile G (2004) Biofield energy healing from the inside. J Altern Complement Med 10: 1107-1113.

[20] Koithan M. (2009) Introducing complementary and alternative therapies. J. Nurse Pract 5: 18-20.

[21] Trivedi MK, Patil S, Shettigar H, Mondal SC, Jana S. (2015) The potential impact of biofield treatment on human brain tumor cells: A. time-lapse video microscopy. J. Integr Oncol 4: 141 .

[22] Trivedi MK, Patil S, Shettigar H, Bairwa K, Jana S. (2015) Phenotypic and biotypic characterization of Klebsiella oxytoca: An impact of biofield treatment. J. Microb Biochem Technol 7: 203-206.

[23] Trivedi MK, Patil S, Shettigar H, Gangwar M, Jana S. (2015) An effect of biofield treatment on multidrug-resistant Burkholderia cepacia: A. multihost pathogen. J Trop Dis 3: 167.

[24] Trivedi MK, Patil S, Shettigar H, Gangwar M, Jana S. (2015) An evaluation of biofield treatment on susceptibility pattern of multidrug resistant Stenotrophomonas maltophilia: An emerging global opportunistic pathogen. Clin Microbiol 4: 211.

[25] Trivedi MK, Branton A, Trivedi D, Nayak G, Bairwa K, Jana S. (2015) Physical, thermal, and spectroscopic characterization of biofield energy treated potato micropropagation medium. American Journal of Bioscience and Bioengineering 3: 106-113.

[26] Trivedi MK, Branton A, Trivedi D, Nayak G, Mondal SC, Jana S. (2015) Antibiogram, biochemical reactions and genotyping characterization of biofield treated Staphylococcus aureus. American Journal of BioScience 3: 212-220. 
[27] Trivedi MK, Branton A, Trivedi D, Nayak G, Mondal SC, Jana S. (2015) Biochemical differentiation and molecular characterization of biofield treated Vibrio parahaemolyticus. American Journal of Clinical and Experimental Medicine 3: 260-267.

[28] Trivedi MK, Branton A, Trivedi D, Gangwar M, Jana S. (2015) Antimicrobial susceptibility, biochemical characterization and molecular typing of biofield treated Klebsiella pneumoniae. J. Health Med Inform 6: 206.

[29] Trivedi MK, Tallapragada RM, Branton A, Trivedi D, Nayak G, Latiyal O, Jana S. (2015) Characterization of atomic and physical properties of biofield energy treated manganese sulfide powder. American Journal of Physics and Applications 3: $215-220$.

[30] Trivedi MK, Tallapragada RM, Branton A, Trivedi D, Nayak G, Latiyal O, Jana S. (2015) Analysis of physical, thermal, and structural properties of biofield energy treated molybdenum dioxide. International Journal of Materials Science and Applications 4: 354-359.

[31] Trivedi MK, Branton A, Trivedi D, Shettigar H, Bairwa K, Jana S. (2015) Fourier transform infrared and ultravioletvisible spectroscopic characterization of biofield treated salicylic acid and sparfloxacin. Nat Prod Chem Res 3: 186.

[32] Trivedi MK, Branton A, Trivedi D, Nayak G, Bairwa K, Jana S. (2015) Spectroscopic characterization of disulfiram and nicotinic acid after biofield treatment. J. Anal Bioanal Tech 6: 265.

[33] Trivedi MK, Tallapragada RM, Branton A, Trivedi D, Nayak G, Mishra RK, Jana S. (2015) Biofield treatment: A. potential strategy for modification of physical and thermal properties of gluten hydrolysate and ipomoea macroelements. J. Nutr Food Sci 5: 414.

[34] Trivedi MK, Nayak G, Patil S, Tallapragada RM, Jana S, Mishra RK. (2015) Bio-field Treatment: An effective strategy to improve the quality of beef extract and meat infusion powder. J. Nutr Food Sci 5: 389.

[35] Trivedi MK, Branton A, Trivedi D, Nayak G, Latiyal O, Jana S. (2015) Evaluation of biofield treatment on atomic and thermal properties of ethanol. Organic Chem Curr Res 4: 145.

[36] Trivedi MK, Branton A, Trivedi D, Nayak G, Singh R, Jana S. (2015) Physical, thermal and spectroscopic studies on biofield treated $p$-dichlorobenzene. Biochem Anal Biochem 4: 204.

[37] Trivedi MK, Branton A, Trivedi D, Nayak G, Bairwa K, Jana S. (2015) Physicochemical and spectroscopic characterization of biofield energy treated $p$-anisidine. Pharm Anal Chem Open Access 6: 102.

[38] Trivedi MK, Branton A, Trivedi D, Nayak G, Gangwar M, Jana S. (2015) Agronomic characteristics, growth analysis, and yield response of biofield treated mustard, cowpea, horse gram, and groundnuts. International Journal of Genetics and Genomics 3: 74-80.

[39] Trivedi MK, Branton A, Trivedi D, Nayak G, Gangwar M, Jana S. (2015) Analysis of genetic diversity using simple sequence repeat (SSR) markers and growth regulator response in biofield treated cotton (Gossypium hirsutum L.). American Journal of Agriculture and Forestry 3: 216-221.
[40] Chereson R. (2009) Bioavailability, bioequivalence, and drug selection. In: Makoid CM, Vuchetich PJ, Banakar UV. (Eds) Basic pharmacokinetics ( ${ }^{\text {st }}$ Edn) Pharmaceutical Press, London.

[41] Blagden N, de Matas M, Gavan PT, York P. (2007) Crystal engineering of active pharmaceutical ingredients to improve solubility and dissolution rates. Adv Drug Deliv Rev 59: 617630.

[42] Trivedi MK, Mohan TRR. (2016) Biofield energy signals, energy transmission and neutrinos. American Journal of Modern Physics 5: 172-176.

[43] Alexander L, Klug HP. (1950) Determination of crystallite size with the X-Ray Spectrometer. J. App Phys 21: 137.

[44] Langford JI, Wilson AJC. (1978) Scherrer after sixty years: A. survey and some new results in the determination of crystallite size. J. Appl Cryst 11: 102-113.

[45] Raza K, Kumar P, Ratan S, Malik R, Arora S. (2014) Polymorphism: The phenomenon affecting the performance of drugs. SOJ Pharm Pharm Sci 1: 10.

[46] Brittain HG. (2009) Polymorphism in pharmaceutical solids in Drugs and Pharmaceutical Sciences, volume 192, 2nd Edn, Informa Healthcare USA, Inc., New York.

[47] Thiruvengadam E, Vellaisamy G. (2014) Polymorphism in pharmaceutical ingredients a review. World Journal of Pharmacy and Pharmaceutical Sciences 3: 621-633.

[48] http://www.dissolution.com/ddg/showthread.php?2366Surface-Area- $v s$-Particle-Size.

[49] Mosharrof M, Nyström C. (1995) The effect of particle size and shape on the surface specific dissolution rate of microsized practically insoluble drugs. Int J. Pharm 122: 3547.

[50] Murray HH, Lyons SC. (1960) Further correlation of kaolinite crystallinity with chemical and physical properties. Clays Clay Miner 8: 11-17.

[51] Sun J, Wang F, Sui Y, She Z, Zhai W, Wang C, Deng Y. (2012) Effect of particle size on solubility, dissolution rate, and oral bioavailability: Evaluation using coenzyme $\mathrm{Q}_{10}$ as naked nanocrystals. Int J Nanomed 7: 5733-5744.

[52] Khadka P, Ro J, Kim H, Kim I, Kim JT, Kim H, Cho JM, Yun G, Lee J. (2014) Pharmaceutical particle technologies: An approach to improve drug solubility, dissolution and bioavailability. Asian J. Pharm Sci 9: 304-316.

[53] Buckton G, Beezer AE. (1992) The relationship between particle size and solubility. Int J Pharmaceutics 82: R7-R10.

[54] Stuart BH. (2004) Infrared spectroscopy: Fundamentals and applications in Analytical Techniques in the Sciences. John Wiley \& Sons Ltd., Chichester, UK.

[55] Hesse M, Meier H, Zeeh B. (1997) Spectroscopic methods in organic chemistry, Georg Thieme Verlag Stuttgart, New York.

[56] Bajaj S, Singla D, Sakhuja N. (2012) Stability testing of pharmaceutical products. J.. App Pharm Sci 2: 129-138. 